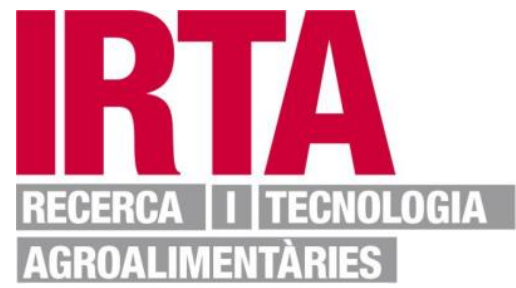

This document is a postprint version of an article published in Food Policy (C) Elsevier after peer review. To access the final edited and published work see https://doi.org/10.106/j.foodpol.2018.08.003 


\section{Effectiveness of a Carbon Tax to promote a climate-friendly food consumption}

\section{Introduction}

Our current dietary habits are a major contributor to climate change because the "seed-to-table” food chain produces an immense amount of greenhouse gases (GHGs) (Castellón et al., 2015). For instance, in Spain, the agricultural sector contributes $14 \%$ of the country's total greenhouse gas (GHG) emissions (Bourne et al., 2012). Hedenus et al. (2014) showed that emission reduction in the agro-food sector can be achieved by: 1) productivity improvements; 2) technological changes (supply-side measures); and 3) changes in consumption behaviour (demand-side measures). Supply side measures such as command-and-control regulations, capand-trade systems or Pigovian (corrective) taxes, have been applied extensively in the European Union (Máca et al., 2012). However, the use of command-and-control measures has been found to be economically inefficient and does not lead to optimal production, when compared to cap-and-trade measures or Pigovian taxes (Burchell \& Lightfoot, 2001)

Pigou (1928) proposed that governments should influence the behaviour of economic agents causing negative (positive) externalities through taxes (subsidies) (Endres, 2010). Influencing suppliers through taxes is a delicate issue because of “carbon leakage " (Wirsenius et al., 2011) and high monitoring costs (Schmutzler \& Goulder, 1997). From the demand side, the relevance of a Pigovian tax on unhealthy/high-carbon-footprint foods is justified under the assumption

\footnotetext{
${ }^{1}$ The European Commission defines carbon leakage as the situation that may occur if, for reasons of costs related to climate policies, businesses were to transfer production to other countries with laxer emission constraints.
} 
1 that the food industry is close to perfect competition ${ }^{2}$. Under such an assumption, the incidence

2 of a Pigovian tax is irrelevant, whether applied to the supply side or the demand end. For this reason, several studies have shown that imposing Pigovian taxes on food demand rather than on food supply constitutes a cost-efficient emission reduction strategy (Edjabou \& Smed, 2013). Consumption taxes are also more attractive from the climate perspective (Mytton et al., 2012). Säll \& Gren (2015) and Wirsenius et al., (2011) argued that the tax should be imposed on consumption and not directly on the emissions. This preserves the competitiveness of domestic products in relation to imported ones and it efficiently allows consumers to adjust to the taxes according to their efficient level of consumption (internalizing the externality).

Influencing consumer behaviour through food taxes is not new. Several countries have introduced taxes on food consumption as a way of internalizing negative externalities associated with the intake of unhealthy and environmentally unfriendly food products (Springmann et al., 2016). In an attempt to improve health, in 2010 Denmark increased the existing taxes on some sugar products, soft drinks and cigarettes and introduced a tax on saturated fat in October 2011 (Smed, 2012). In 2011, Hungary also passed an excise tax on foods and beverages high in caffeine, fat, and sugar, which included both soft drinks and energy drinks (Escobar et al., 2013) with the objective of internalizing the cost of obesity related diseases. Similarly, Finland, in 2011, introduced a tax on sweets, ice-creams and soft drinks. Following Hungry, Denmark and Finland, France introduced the 'soda tax' in January 2012 with the aim of reducing unhealthy consumption of sugar or sweeteners (Berardi et al., 2016). The Mexican government in September 2013 imposed excise taxes on sugar sweetened beverages and a sales tax on several highly energy dense foods (Colchero et al., 2016) to reduce

\footnotetext{
${ }^{2}$ According to Edjabou and Smed (2013) food markets are characterised by near-perfect competition, which implicitly assumes that the tax incidence between food producer and consumer does not depend on whether it is the producer or the consumer who is taxed since, on a long term basis, the tax in both cases is likely to end at the consumer. We acknowledge that a deviation from this assumption will have serious consequences on our results. As such the result should be interpreted with caution.
} 
1 the prevalence of obesity and related diseases. Berkeley (California, USA) has taxed sugar-

2 sweetened beverages (Cornelsen \& Carreido, 2015).

3 In a meta-analysis, Escobar et al. (2013) showed that increasing the prices of sugar-sweetened 4 beverages (SSBs) led to a reduction in the prevalence of obesity and overweight. Jensen \&

5 Smed (2013) found that the consumption of fats in Denmark dropped by $10 \%$ following the fat

6 tax in 2011 while a later study by Smed et al. (2016) found that the consumption of saturated

7 fat decreased by about 4-5\% on average. Escobar et al. (2013), Jensen \& Smed (2013) and

8 Smed et al. (2016) provide evidence that seems to suggest that taxes on food can change 9 consumption behaviours and internalize the associated negative externalities.

Based on the evidence provided, the objective of this paper is to evaluate the potential effects of imposing a "Pigovian” $\mathrm{CO}_{2}$ equivalent tax on food products in Catalonia (North-East Spain). From food demand elasticities, we show that levying a $\mathrm{CO}_{2}$ equivalent tax has three effects: 1) reduction in the consumption of high carbon footprint foods with consequences on nutrient intake and the quality of diet; 2) a reduction in GHG emissions; and 3) welfare effects.

Despite the increasing importance of this topic in the policy arena, as well as among researchers, to the best of our knowledge, only a very few papers have been published dealing with the impact of taxation of unhealthy food consumption on $\mathrm{CO}_{2}$ equivalent emissions reduction (Briggs et al., 2013; Edjabou \& Smed, 2013; Garcia-Muros et al., 2017; Säll \& Gren, 2015; Wirsenius et al., 2011). Wirsenius et al. (2011) found that EU-27 could reduce approximately 32 million tons of $\mathrm{CO}_{2}$-eq if they imposed a GHG weighted tax on animal food products corresponding to 60 Euro per ton CO2-eq. Similarly, Edjabou \& Smed (2013) internalizing the social costs of greenhouse gas emissions by imposing $\mathrm{CO}_{2}$-eq consumption taxes on 23 different foods found that emission would decline by $2.3-8.8 \%$ and $10.4-19.4 \%$ in 
1 Wirsenius et al., (2011) and found that imposing a tax on all meat and dairy products decreased emissions of GHG, nitrogen, ammonia and phosphorus from the livestock sector by up to $12 \%$. Garcia-Muros et al., (2017) evaluated the implications of levying consumption taxes on food products in Spain based on their carbon footprint. Using demand elasticities computed from

5 the LAIDS model showed that a $\mathrm{CO}_{2}$-eq tax policy could reduce emissions and, at the same time, help to change consumption patterns towards healthier diets.

7 The above papers provide sound empirical evidence that taxes on food products based on their 8 carbon footprints can lead to decreased $\mathrm{CO}_{2}$-eq emission and improve dietary compositions. 9 However, they are not exempted of criticisms. From a methodological point of view, past studies have relied on the AIDS model, ignoring the impact of unobserved household heterogeneity in welfare estimates. The second criticism is that with the exception of Edjabou \& Smed (2013), who considered 23 food categories, past literature usually considered a reduced number of food products (meat, meat and dairy,...), ignoring potential substitution effects among the included food categories and those categories excluded from their analysis. In the case of Spain, only Garcia-Muros et al. (2017) have dealt with the distributional effects of carbon-based food taxes. However, our study differentiates from the later in several issues: 1) as mentioned, the demand model used in this study is more flexible about the functional form of the Engle curves and takes into account unobserved household heterogeneity in the welfare calculations; 2) the geographical scope is different, as our study is concentrated on a Spanish region - Catalonia; 3) tax scenarios are different with this study focusing on current EU medium- and long-term emission reduction objectives; and 4) this study focuses on revenue-neutral (compensated) scenarios.

The remainder of the article is structured as follows. Sections 2 and 3 describe the data and the methodological framework used in this study. Section 4 shows and discusses main results. The paper ends with some concluding remarks and limitations. 
2 This study uses microdata: home scan panel data from a sample of 1146 households $^{3}$ in

3 Catalonia (Northeast Spain) collated by Kantar Worldpanel. From the total of 1146 households,

4 only those who had remained in the sample for at least 45 weeks were considered. Purchased

5 quantities and expenditures for each single food product reference have been aggregated to the

6 annual level for each household. The data set contains all day-to-day records of food purchases

7 of Catalonian households in 2012. Each record in the Kantar data set contains detailed product

8 information down to the Universal Product Code (UPC) level, including the store in which the

9 household makes the purchases, product weight, price, unit of measurement, product

characteristics (such as container type, brand, and flavor) and some household sociodemographic characteristics such as nationality, age, social class, presence of kids, number of pets, size of pets etc. Household's also recorded, in a book, non-UPC items as fresh fruits or vegetables, and in-store packaged breads and meats.

Using established Spanish Ministry of Agriculture nutrition-based guidelines, food products have been aggregated into 16 food categories $^{4}$ (alcoholic drinks are not included, while nonalcoholic drinks are included in the residual category for the purpose of this paper) : 1) Grains and grain-based products, 2) Vegetables and vegetable products, 3) Starchy roots, tubers, legumes, nuts and oilseeds, 4) Fruit, fruit products and fruit and vegetable juices, 5) Beef, veal and lamb; 6) Pork, 7) Poultry, eggs, other fresh meat; 8) Processed and other cooked meats, 9) Fish and other seafood, 10) Milk, dairy products and milk product imitates, 11) Cheese, 12) Sugar and confectionary and prepared desserts, 13) Plant based fats, 14) Composite dishes (animal and vegetable composite dishes), 15 Snacks and other foods, 16) Residual category.

\footnotetext{
${ }^{3}$ The sample is designed to represent the sociodemographic characteristics of households in Catalonia. Each household is assigned a weight in order to estimate total consumption for Catalonia. In this study, working with the raw data, only rural households are slightly underrepresented.

${ }^{4}$ The percentage of households with zero expenditures in the 16 food categories is shown in Table 1.
} 
1 To standardize the products, all quantities were converted into kilograms and prices into euros.

2 Similar to Zhen et al., (2014) the lowest level of aggregating the price data was the brand level.

3 The brands were identified as belonging to subgroups and then to one of the 16 commodity

4 groups.

5 To circumvent the problem of unit values encountered in cross-sectional data ${ }^{5}$, we followed

6 Diewert (1998) to construct Fisher price indices ${ }^{6}$ for the 16 food groups in our data using brands

7 as the lowest level of aggregation. The Fisher price index, which is the geometric mean of the

8 Laspeyeres and Paache indices, represents the deviation of the price paid by a household

9 relative to the average household. For instance, to construct the price index for the residual category, we followed the following procedure:

1) Determination of the price per unit for a relatively homogeneous in-quality product. In this was calculated as:

$$
U V_{g j}^{h}=\frac{\sum_{m=1}^{M} p_{m g j}^{h} q_{m g j}^{h}}{\sum_{m=1}^{M} q_{m g j}^{h}}
$$

where $p_{m g j}^{h}$ is the $h$-th household price of the $m$ brand in aggregate product $g$ within the food category $j$, and $q_{m g j}^{h}$ is the $h$-th household quantity purchased of the $m$ brand in aggregate product $g$ within the food category $j$.

\footnotetext{
${ }^{5}$ We have aggregated our panel to a cross-sectional data for the following reasons: first, seasonality effects have to be taken into account. Some seasonal effects are easy to handle but others are not so easy. In case we had had three or four years, this issue would not have been a problem; second, and more relevant, the number of zero purchases increased significantly adding an additional econometric issue. We tried a double hurdle model for that but the joint estimation of a 16-equation multivariate probit and the EASI model was not econometrically feasible due to convergence problems.

${ }^{6}$ Secondly, by implementing the Fisher price index we able to reduce the level of heterogeneity bias in the aggregation of our data into a cross-sectional data and abstract out quality variation due to product heterogeneity (Silver \& Heravi, 2006; Zhen et al., 2014)
} 
1 2) Construction of the Fisher price indices using the $U V_{g j}^{h}$ values obtained in the first stage. The

2 Fisher price index for the $h$-th household food category $j$ is calculated as:

and

$$
P_{F j}^{h}=\sqrt{P_{P j}^{h} * P_{L j}^{h}}
$$

where $P_{L j}^{h}$ and $P_{P j}^{h}$ represent $h$-th household Laspeyres and Paasche price indices for food category $j$, respectively.

$$
P_{P j}^{h}=\frac{\sum U V_{g j}^{h} * q_{g j}^{h}}{\sum U V_{g j} * q_{g j}^{h}}
$$

$$
P_{L j}^{h}=\frac{\sum U V_{g j}^{h} * q_{g j}}{\sum U V_{g j} * q_{g j}}
$$

9 where $U V_{g j}^{h}$ is the unit value for aggregate product $g$ within food category $j$ for the $h$-th household as defined previously, $U V_{g j}$ is the unit value for aggregate product $g$ within food category $j$ for the average household and $q_{g j}$ is the average quantity purchased for aggregate product $g$ within food category $j$ for the average household.

Table 1 shows the main household characteristics of the sample used in this paper. In the upper part, data on food expenditure ${ }^{7}$ shares of the sixteen food groups are provided. As can be observed, the average household spends $21 \%$ of the food expenditure on fruits and fruit products, and milk and milk product imitates, respectively. The next significant food category for the average household is vegetables and vegetable products, followed by poultry, eggs and other fresh meat. The food category that attracted the lowest expenditure share is snacks and

\footnotetext{
${ }^{7}$ Food expenditure used in our data refers to food-at-home expenditure. Kantar Worldpanel did not provide data on foodaway-from-home neither on household income. Henceforth, we have assumed weak separability of food-at-home expenditure on total expenditure. Instead of income, the dataset provides information about the social class the household belongs. Social class is defined by the following four groups of household characteristics: 1) Occupation of all household members; 2) General characteristics of the living place (size, location, ownership,...); 3) Household equipment; and 4) Number and characteristics of owned vehicles.
} 
1 other foods. Among the socio-demographic characteristics, for the purposes of this study and

2 taking into account the information available in the dataset about households' characteristics,

3 we have included age, presence of kids and the social class, as in Ricciuto et al., (2006). Table

41 shows that, 21\%, 20\% and 59\% percent of the households belong to the high, low and middle

5 social class category, respectively. Households with kids were in the minority representing

$6 \quad 35.6 \%$ of the sample.

8 Methodological framework

\section{$9 \quad$ Estimating Food Price Elasticities}

10 Food price elasticities have been calculated by estimating an approximate EASI demand model

11 (Lewbel \& Pendakur, 2009), which incorporates household characteristics. The EASI demand model has several advantages over the traditional Almost Ideal Demand System (AIDS), as it derives the Implicit Marshallian demand function which combines desirable properties of both the Hicksian and Marshallian demand functions. Moreover, the error terms can be interpreted as unobserved preference heterogeneity among individuals and Engle curves can adopt any shape over real expenditures. Finally, similar to the AIDS model, we can estimate a linear approximation which generates results similar to the full model.

The approximate EASI demand equation expresses the budget shares, $w_{h i}$, as a function of food prices $P$, real household food expenditure $\widetilde{y}$, and K socio-demographic characteristics $z$ :

$$
w_{h i}=\sum_{r=1}^{5} v_{i r} \tilde{y}_{h}^{r}+\sum_{j=1}^{N} a_{i j} \ln P_{h j}+\sum_{j=1}^{N} b_{i j} \ln P_{h j} \tilde{y}_{h}+\sum_{k=1}^{K} c_{i k} z_{h k}+\sum_{k=1}^{K} d_{i k} z_{h k} \tilde{y}_{h}+u_{h i}
$$


1 where $w_{h i}$ is the budget share of the i-th category for the h-th household; $N$ is the number of

2 food categories; $\tilde{y}_{h}$ is the real food expenditure for $h$-th household $\left(\tilde{y}_{h}=\ln x_{h}-\sum_{j}^{N} \bar{w}_{h}\right) ; 5$ is

3 the highest order of polynomial in $\tilde{y}_{h}$ to be determined empirically; $P_{h j}$ is the price index of the

$4 \quad j$-th food category paid by the $h$-th household; $K$ is the number of exogenous demand shifters;

$5 \quad z_{h k}$ is the $k$-th demand shifter for the $h$-th household, with $z_{h 1}$ being a constant; $a_{i j}, b_{i j}, c_{i k}, d_{i k}$

6 and $v_{i r}$ are parameters to estimate; and $u_{h i}$ is error term, which accounts for unobserved

7 preference heterogeneity. For the model to be consistent with theory, the budget share

8 equations $w_{h i}$ are required to satisfy the properties of adding-up, linear homogeneity and

$9 \quad$ Slutsky symmetry.

10 The EASI demand system was estimated using 3-Stage least Squares to account for endogeneity. There are two sources of endogeneity. First, the presence of budget shares in the stone index makes this index to be endogenous ${ }^{8}$. Second, the real food expenditure $\left(\tilde{y}_{h}\right)$ is a function of the endogenous food group expenditure $\left(x_{h}\right)$. In our conditional food-at-home demand model, we have controlled for this form of endogeneity by using social class as a proxy for income to instrument for food groups expenditure $\left(x_{h}\right)^{9}$.

By taking the derivatives of (5) with respect to log prices and expenditure, we get the Hicksian demand semi-elasticities, which were converted into price elasticities following Castellón et al. (2015) and expenditure elasticities following Zhen et al. (2014).

- Hicksian price elasticities for $i$-th good with respect to the price of the $j$-th food product was calculated as:

\footnotetext{
${ }^{8}$ Lewbel \& Pendakur (2009) and Zhen et al., (2014) have shown that this source of endogeneity in demand models is numerically unimportant.

${ }^{9}$ Another way of dealing with this form of endogeneity is to estimate an incomplete food-at-home demand model as in Zhen et al. (2014) and ignore the need to use instruments. However, this strategy needs information about household income which is not available in our dataset.
} 


$$
H_{i j}=\frac{\left(a_{i j}+b_{i j} \widetilde{y}\right)}{w_{i}}+w_{j}-\delta_{i j}
$$

$2 \quad$ where $\delta_{i j}=1$ if $i=\mathrm{j}$, and 0 otherwise.

- The $\mathrm{N} x 1$ vector of food expenditure elasticities, FE was calculated as:

$$
F E=(\operatorname{diag}(W))^{-1}\left[\left(I_{j}+X P^{\prime}\right)^{-1} X\right]+1_{j}
$$

where $\boldsymbol{W}$ is the $N \times 1$ vector of observed budget shares, $\boldsymbol{X}$ is a $N \times 1$ vector whose $i$-th element equals $\sum_{r=1}^{5} r v_{i r} y^{r-1}+d_{i k} z+b_{i j} p, \quad \boldsymbol{P}$ is the $N \times 1$ vector of log prices, and $1_{j}$ is a $N \times 1$ vector of ones.

- The Marshallian price elasticity, $\boldsymbol{\varepsilon}_{\boldsymbol{i} \boldsymbol{j}}$, were recovered from the Slutsky equation using:

$$
\varepsilon_{i j}=H_{i j}-w_{j} * f e_{i}
$$

where $\boldsymbol{f} \boldsymbol{e}_{\boldsymbol{i}}$ is the $i$-th element of $\boldsymbol{F E}$.

\section{Measuring the impact of $\mathrm{CO}_{2}$ equivalent $\left(\mathrm{CO}_{2}-\mathrm{Eq}\right)$ tax on food demand}

To measure the impact of $\mathrm{CO}_{2}$-eq tax on food demand, we needed data on $\mathrm{CO}_{2}$ emissions per kilogram of food products. Although several studies have provided some figures, there is no single study that covers all the food categories considered in this study in Spain (Macdiamid et al., 2012). For complete and comprehensive estimates, $\mathrm{CO}_{2}$ equivalent emissions for major food products consumed in the EU were taken from Hartikainen \& Pulkkinen (2016) ${ }^{10}$. Their estimates were based on the following assumptions: 1) they are restricted to the food chain (from primary production to final consumption, encompassing processing, packaging [including recycling of packaging material], storing and cooking); 2) transport activities

\footnotetext{
${ }^{10}$ Although this dataset contains information for a large number of food products, we could not find information for 9 out of the 112 products considered in this study (minced beef; all other beef and veal; all other lamb; pork joints; pork chops; all other pork; chicken and turkey, cooked; turkey, uncooked - whole turkey or turkey pieces; bacon and ham, cooked). In the case of missing information, we took the data from Bonnet et al. (2018).
} 
1 (including consumers' displacement to retail outlets) are not included; 3) GHG emissions due

2 to food waste were not accounted for; and 4) direct land-use changes were not considered due

3

4

5 limitation to using this data due to differences in food production systems in Spain and other

6 EU countries, we consider that the data set will serve the purposes of this study because it uses

7 a common framework to estimate GHG emissions for a large list of food products.

8 To determine the average $\mathrm{CO}_{2}$-eq emissions from each food category, we multiplied the 9 average daily consumption $(\mathrm{kg})$ of each food group by their corresponding average $\mathrm{CO}_{2}$-eq emissions to obtain the average $\mathrm{CO}_{2}$-eq emissions per kg of food category per day for the 16 food groups considered in this study (see Table 2). The impact of imposing a carbon/green tax on demand for food has been analysed, taking into account the price/ton of $\mathrm{CO}_{2}$ equivalent emissions for each of the 16 food categories. Previous studies have used a wide range of values ranging from 0 Euro up to 365 Euro (Stern, 2007). To cite only two examples, Edjabou \& Smed (2013) based on the Tol (2012) and (Stern, 2007) estimates, assumed a carbon social cost of 30 Euro per ton and a $\mathrm{CO}_{2}$ equivalent of 100 Euro per ton, respectively. (Irz et al., 2015) assumed a value of 32 Euro, based on the meta-analyses carried out by Tol (2012).

\section{Include Table 2 here}

\section{Simulation scenarios}

This study aims to simulate two tax scenarios (compensated and uncompensated), following Edjabou \& Smed (2013). In the uncompensated (U) scenario, taxes were imposed on all food

\footnotetext{
${ }^{11}$ Hartikainen \& Pulkkinen (2016) estimates are based on ready-to-eat foods. They used the conversion factor proposed by McCance and Widdowson (2015). However, in their dataset, transport emissions are not considered. For the purpose of our estimation, we assume that our food products are all ready-to-eat (ignoring the impact of exclusion or inclusion of inedible parts).
} 
1 groups proportional to their carbon footprint. In the compensated (C) scenario, the taxes were

2 imposed, as in Säll \& Gren (2015), only on those food categories that generate higher GHG-

3 emissions: all meats, milk and dairy products, cheese and composite dishes (see Table 2).

4 Additionally, tax revenues generated from the above mentioned taxed foods were used to

5 subsidize the rest of the foods that generate comparatively lower $\mathrm{CO}_{2}$-eq emissions per $\mathrm{kg}$.

6 Under both scenarios ( $\mathrm{U}$ and $\mathrm{C}$ ), this study considers two different policy goals taking into

7 account the EU's medium- and long-term carbon emission reduction objectives. The EU

8 proposes a social cost of $\mathrm{CO}_{2} / \mathrm{t}$ equivalent emission of $56 \mathrm{EUR}$ (scenario 1) and $200 \mathrm{EUR}$

9 (scenario 2) to reduce total greenhouse gas emissions by $20 \%$ and $60 \%$ by 2020 and 2050, respectively, across the EU (Quinet, 2009). Thus, in total, this study considers four tax scenarios U1, U2, C1 and C2 (Table 3)

In scenarios U1 and U2 (uncompensated case under the two policy goals) and following Baumol \& Oates (1975), the taxes imposed on each food category was calculated as follows:

$$
\boldsymbol{t}_{\boldsymbol{i}}=\boldsymbol{\rho}_{\boldsymbol{i}} * \boldsymbol{\varphi}
$$

where $t_{i}$ is the tax imposed on the $i$-th food category, $\rho_{i}$ is the used average $\mathrm{CO}_{2}$ equivalent for the $i$-th food group and $\varphi$ is the social cost of releasing $1 \mathrm{~kg}$ of GHG measured in $\mathrm{CO}_{2}$ equivalents in scenarios 1 or 2 .

In scenarios C1 and C2 (compensated case), we have followed the seminal paper by Edjabou \& Smed (2013) to create revenue-neutral policy scenarios. Under both cases, the new price, $\boldsymbol{p}_{\boldsymbol{i 1}}$ for the subsidized $i$-th food category that was not taxed was calculated as:

$$
\boldsymbol{p}_{\boldsymbol{i 1}}=p_{i 0}-\emptyset * p_{i 0}
$$


1 where $\varnothing$ is a consistently positive factor and $p_{i 0}$ is the price of the $i$-th food category with the

$2 \mathrm{CO}_{2}$-eq tax from scenarios U1 or U2 (Table 3). The value of $\varnothing$ is determined as the value where

3 the total tax revenue after the price change equals the tax revenue before the price change.

4 Based on the above method, the subsidies $(\varnothing)$ generated for scenarios C1 and C2 are: $\emptyset_{C 1}=8 \%$

5 and $\emptyset_{C 2}=27 \%$, respectively.

6 Table 4 summarizes the price changes under the different tax scenarios considered in this paper.

7 As can be observed, in the two uncompensated scenarios, but mainly in scenario U2, price

8 changes range from about 2\% (starchy roots, legumes and pulse category) to 44\% (beef, veal

9 and lamb category) and 55\% (composite dishes). Even if the policy goal is aimed to be achieved exclusively by a tax policy, it is unreliable assuming that policy makers would tax food products generating prices outside their natural variation. Moreover, taxing all categories would not be plausible, as the potential reduction in the consumption of all food products could have negative consequences on households that are poorer as well as on the overall population's quality of diet (i.e. the reduction in the consumption of fruits and vegetables). For this reason, for the rest of this study, we will concentrate all the analyses in the compensated or revenue neutral scenarios. Under such scenarios, all untaxed food categories are subsidized equally while taxed foods remained as in the uncompensated case.

The percentage reduction in the quantities consumed after imposing the taxes were calculated taking the own- and cross- price elasticities into account:

$$
\frac{\Delta Q_{i}}{Q_{i}}=\sum_{j}^{N} \varepsilon_{i j} * \frac{\Delta p_{i}}{p_{i}}
$$

21 where $\frac{\Delta P_{i}}{P_{i}}$ and $\frac{\Delta Q_{i}}{Q_{i}}$ represent the percentage change in prices and quantities of the $i$-th food 22 group after the tax, respectively (Säll \& Gren, 2015). 
1 Finally, the post-tax change in $\mathrm{CO}_{2}$ equivalent emission for the $h$-th household $\Delta \boldsymbol{E} \boldsymbol{m}_{\boldsymbol{h}}$ was

2 obtained by multiplying the change in consumption for the $i$-th food category, $\Delta \boldsymbol{Q}_{\boldsymbol{i}}$ by the $\mathrm{CO}_{2}$

3 equivalent emission per $\mathrm{kg}$ of the $i$-th food category.

4

5

6

7

8

9

$$
\Delta \boldsymbol{E} \boldsymbol{m}_{\boldsymbol{h}}=\sum_{j}^{N} \rho_{i_{j}} * \Delta \boldsymbol{Q}_{\boldsymbol{i}}
$$

where $\rho_{i j}$ is the used average $\mathrm{CO}_{2}$ equivalent for the $i$-th food group and $\Delta \boldsymbol{Q}_{\boldsymbol{i}}$ is the change in quantity taking into account own- and cross- price elasticities.

\section{Include Table 4 here}

Estimating the impact of $\mathrm{CO}_{2}$-eq tax on household's welfare

In order to calculate the impact of the aforementioned taxes on a household's welfare, being consistent with previous literature, we have assumed that the food supply is perfectly inelastic and is not influenced by the $\mathrm{CO}_{2}$-eq tax. This implicitly assumes that the tax burden between Catalonian food producers and consumers does not depend on whether it is the producer or the consumer who is taxed, since in the long term, the tax is likely to end on the consumer ${ }^{12}$. Under this assumption, welfare estimates are calculated through the so-called log of living cost index of Lewbel \& Pendakur (2009) which takes into account both first-order and second-order effects. The first order-effect assesses the distributional impact of the tax imposition on each food category as the product of its corresponding budget share by the price change in that food category, while the second order-effect considers how consumers react to price changes:

$C\left(p_{1}, u, z, \varepsilon\right)-C\left(p_{0}, u, z, \varepsilon\right)=\left(p_{i 1}-p_{i 0}\right)^{\prime} w_{0}+0.5\left(p_{i 1}-p_{i 0}\right)^{\prime}\left(\sum_{j}^{N} a_{i j}+b_{i j} \widetilde{y}\right)\left(p_{i 1}-p_{i 0}\right)$

\footnotetext{
${ }^{12}$ We acknowledge that a deviation from this assumption could have consequences on our results. First, the tax burden will be shared by both consumers and producers, affecting the competitiveness of domestic firms. Second, the magnitude of the impact on consumption (reduction in quantity and emissions) could likely to be lower. However, it is also true that in the short run producers cannot modify their supply taking into account the existence of fix costs.
} 
1 The term $\left(\boldsymbol{p}_{\mathbf{1}}-\boldsymbol{p}_{\mathbf{0}}\right)^{\prime} \boldsymbol{w}_{\mathbf{0}}$ in (14) is the Stone index for the price change while

$2 \boldsymbol{0 . 5}\left(\boldsymbol{p}_{i 1}-\boldsymbol{p}_{i 0}\right)^{\prime}\left(\sum_{j}^{N} \boldsymbol{a}_{i j}+\boldsymbol{b}_{i j} \widetilde{y}\right)\left(\boldsymbol{p}_{i 1}-\boldsymbol{p}_{\boldsymbol{i} 0}\right)$ models substitution effects resulting from price

3 changes.

4 To estimate the welfare effects for the $k$-th social demographic group, we subsampled the data

5 based on the $k$-th demographic group to estimate the average prices and average budget shares,

6 which were introduced into equation (14).

\section{$8 \quad$ Results and Discussion}

$9 \quad$ Price and food expenditure elasticities

10 The EASI demand model in (5) has been estimated imposing adding-up, homogeneity and symmetry ${ }^{13}$. Several Wald tests have been carried out to check for model adequacy. In relation to the functional form of the Engle curve, we followed a sequential procedure. We considered first a 5-degree polynomial and test for the significance of the fifth parameter. As the p-value was 0.75 , we consider a fourth-degree polynomial as test for the significance of the fourth parameter. Its p-value was 0.50 . We repeated the process with a cubic functional form and here we obtained a 0.005 p-value, indicating that a cubic functional form was appropriate in our case. Finally, we tested for the joint significance of the interaction parameters between sociodemographic variables and prices and real food expenditure, respectively. Results indicated that parameters associated to interactions with prices were not jointly statistically significant (p-value 0.78 ), while were significant in the case of real expenditure (p-value 0.003).

\footnotetext{
${ }^{13}$ Taking into account how price indices were calculated based on unit values, and as the households choose prices and budget-shares simultaneously, following Dhar et al. (2003) we performed a Hausman test for price endogeneity by comparing the OLS estimated model with 3SLS estimator including region and nationality as instruments. Results indicated that endogeneity was not an issue in our model.
} 
1 Table 5 shows the calculated food expenditure as well as Marshallian own- and cross-price

2 elasticities ${ }^{14}$. Food expenditure elasticity estimates are statistically significant at the $1 \%$ level

3 and positive. Three food groups out of the 16 are food expenditure elastic, including vegetables

4 and vegetable products, fruit and fruit products and poultry, eggs and other fresh meats. Again,

5 in this case, results do not significantly differ from previous studies, taking into account again

6 that sample periods and food categories are different. Garcia-Muros et al., (2017) found Fruits

$7 \quad$ (1.02) and Vegetables (1.03) to be slightly expenditure elastic. Similarly, Molina (1994) and

8 Laajimi et al. (1997) found fruit and vegetables to have expenditure elasticity of 1.333 and

9 1.034, respectively, in Spain. Contrary to our results, Garcia-Muros et al., (2017) found poultry

10 to be inelastic (0.850). However, Molina (1994) and Laajimi et al. (1997) summed all meat

11 into one category and found meat consumption to be expenditure elastic in Spain.

Table 5 also shows the own price elasticities at the sample means. All own-price elasticities estimates are statistically significant at the $5 \%$ level and negative, except for beef, veal and lamb and the residual category, which are significant at the $10 \%$ level. All food categories have absolute price elasticities less than unity, except for the residual food category. We found price elasticities for fruit and fruit products and vegetable and vegetable products to be -0.75 and 0.65, respectively. This is in line with the previous findings from Molina (1994) and Laajimi et al. (1997), although both studies combined fruits and vegetables into one single category and found price elasticities to be -0.68 and -0.84 , respectively.

All animal and dairy products were found to be price inelastic. Beef, veal and lamb had the lowest price elasticity (-0.16). However, this result is consistent with previous studies in Spain using cross-section data. For instance, Angulo et al. (2008) found a price elasticity for all meats,

\footnotetext{
${ }^{14}$ For comparative purposes, we have provided the elasticity estimates for the QUAIDS model in the Appendix.
} 
1 jointly considered, of -0.399 , which corresponds to the average of all price elasticities found in

2 this paper for meat products.

3 In relation to cross-price elasticities (Table 5), we have found 150 complementarities among

4 food categories and 115 substitutions. Most of the cross-price elasticities are significant and

5 plausible. For instance, we found that poultry, eggs and other fresh meat category is a close

6 substitute for all animal products including fish and marine products. We also found

7 complementarity between all animal products and fruits and fruit products. Grains and grain

8 based products and vegetable and vegetable products are complement to all animal products,

9 starchy roots, tubers, legumes, nuts and oil seeds. Finally, milk and other dairy products were found to be complementary to cheese.

Include Table 5 here

Impact of a $\mathrm{CO}_{2}$ tax on household $\mathrm{CO}_{2}$-eq emissions and food consumption

Figure 1 shows, for the average household, the reduction in $\mathrm{CO}_{2}$-eq emissions after the tax imposition, under the compensated tax scenarios, taking into account both price and cross-price elasticities. As can be observed, the mean reduction in emissions ranges from $2 \%$ to $6.4 \%$, depending on the associated damage cost of emissions.

Figure 2 shows the impact on the consumption of the different food categories considered in this study. The consumption of taxed food categories would decrease, particularly in the case of pork. The impact on beef and lamb would be lower in comparison with other studies, such as Henchion et al. (2014) and Säll \& Gren (2015), as in the case of Catalonia, the beef, veal and lamb consumption is significantly price inelastic and its budget share is relatively low in 
1 comparisons with other meats. On the other hand, the consumption of subsidized food

2 categories would increase. The magnitude of the increase highly depends on the public

3 revenues from taxed products. As the public revenue from the taxed foods increases, the

4 compensation to subsidized categories also increase generating higher consumption levels.

5 This is particularly relevant in the residual category; snacks and other foods; and starchy roots,

6 tubers, legumes, nuts and oilseeds category. Cheese consumption would increase despite the

7 fact that it was taxed, which could be due to the strong complementarity with subsidized foods.

Include Figure 2 here

\section{Welfare impacts of $\mathrm{CO}_{2}$ equivalent taxes}

Welfare effects have been calculated using the compensated variation based on the log of the living cost index proposed by Lewbel \& Pendakur (2009) for the average household, as well as for the different types of households, taking into account the socio-demographic characteristics that were included in the EASI demand system (the age of the household head and the presence of children).

The log of living cost index measures the change in the initial expenditure that a household should require to maintain the same food consumption level than before the imposition of the tax. In both scenarios, by definition, the public revenue generated is set to zero and it is allocated to subsidize food products with low $\mathrm{CO}_{2}$-eq footprint. The first row in Table 6 shows the food expenditure compensation that the average household would receive due to price increases. Results indicate that in the first scenario (reducing carbon emissions by $20 \%$ by 2020), after the imposition of the taxes and subsidies, on average, consumers would save about $0.25 \%$ of their initial expenditure. In scenario C2 (reducing carbon emissions by $60 \%$ by 2050), 
1 consumers would require a slight increase of $0.41 \%$ in their initial expenditure to maintain their

2 current consumption patterns.

3 Table 6 also shows the distributional impact of the tax on different household groups. In

4 scenario C1, all household groups save on their initial expenditure, however, the level of

5 savings differ. For instance, in households without kids or when the household head is older

6 savings would be higher than in other socioeconomic segments. Under scenario C2 (see table

73 for definitions), all households except pensioners would require an increase in their initial

8 expenditure to maintain the same food consumption level. Economically, scenario C1 would

9 be more cost efficient for government and less regressive across different consumer groups.

Include Table 6 here

Impact of CO2-eq tax on diet quality

12 To end with the impact assessment of the alternative tax scenarios, in this section we aim at reporting their potential effect on diet quality. Although there is a vast amount of literature about alternative measures for diet quality ${ }^{15}$, here we have used a relatively simple approach by taking into account the 2005 Spanish Strategy for Nutrition, Physical Activity and Obesity Prevention (NAOS), which recommended that dietary proteins should provide between 10\% and $15 \%$ of total calorie intake; total dietary fats should not exceed $30 \%$ of the daily caloric intake; and total carbohydrates should represent between $50 \%$ and $60 \%$ of the energy intake. As our dataset only contains household values, we have calculated average per capita adult equivalent values. Figure 3 shows the main results from this analysis. The last two bars correspond to current nutrient ratios and the NAOS recommended values, respectively. The remaining bars correspond to each of the tax policy scenarios. Our result indicates that that the

\footnotetext{
${ }^{15}$ The definition of diet quality and its empirical determination is beyond the scope of this paper.
} 
1 current macronutrient intake significantly exceeds the recommended values in the case of lipids

2 (42.04\%) and very slightly in the case of proteins (16.00\%). Consequently, the intake of carbohydrates is lower than the recommended values (41.96\%). These results are consistent with previous studies in Spain suggesting an overconsumption of fats (Moreno et al., 2002), which is one of the main reasons for the rapid increase of the prevalence of obesity and healthrelated diseases compared to other EU countries (Garcia-Goñi \& Hernández-Quevedo, 2012).

Include figure 3 here

Any tax policy to reduce $\mathrm{CO}_{2}$-eq emissions would produce results that would either generate a more or less equilibrated diet depending on the policy scenario. Our results indicate that the total calorie intake would not significantly change in any tax scenario (the current caloric intake of $1.816 \pm 512 \mathrm{Kcal} /$ capita/day would decrease by $0.2 \%$ under scenario C1 but increase by $0.1 \%$, under scenario C2. The impact on the quality of diet would be limited but would go in the right direction. As Figure 3 shows, there would be a reduction in the intake of lipids and proteins together with an increase in that of carbohydrates. For instance, in scenario C2, the intake of proteins and lipids would decrease by $2 \%$ and $5.6 \%$, respectively, while that of carbohydrates would increase by $4.3 \%$. In order to complete the overview about the potential impact of the two tax scenarios, we have calculated the changes in the most relevant nutrients intake (Figure 4). Consistent with the previous results, changes are higher in scenario C2 (reducing carbon emissions by $60 \%$ by 2050). For instance, saturated fat and cholesterol intake would be reduced due to the reduction in the consumption of meat, composite dishes and lipids (Figure 2), while carbohydrates intake would increase. On the negative side, the sugar intake would increase due to the increase consumption of cereals and starchy roots as these food categories would be subsidized as a result of their low contribution to $\mathrm{CO}_{2}$-eq emissions. Similarly, the consumption of healthy fatty acids like mono- and poly- saturated acids decreases. Summing up, our results suggest that $\mathrm{CO}_{2}$ tax scenarios could lead to nutrient 
1 redistribution but not enough to meet the recommended dietary requirements in line with the

2 NAOS strategy ${ }^{16}$. In addition, dietary changes results in trade-offs between healthy fatty acids, such as mono-saturated and poly-saturated fatty acids, and saturated fatty acids.

\section{$5 \quad$ Concluding remarks}

6 The study aimed at assessing the impact of introducing a Pigovian or $\mathrm{CO}_{2}$-eq tax on food

7 demand, dietary composition, emission reduction and consumer welfare in Catalonia

8 (Northeast Spain). Alternative tax policy scenarios have been considered, which, in essence,

9 reflect the alternative social cost of emissions or alternative tax magnitudes. In any case, the scenarios have been chosen by taking into account real scenarios discussed in the EU. The methodological framework has been based on food expenditure as well as on own- and crossprice elasticities calculated from estimating an EASI food demand system. From elasticity estimates, the paper has assessed the impact of the tax on $\mathrm{CO}_{2}$-eq emission, diet quality and household's welfare.

Results obtained in this study suggest that taxing all food categories depending on their contribution to $\mathrm{CO}_{2}$-eq emission would be unrealistic, as it would generate significant price changes, which would increase up to 55\% (very far from their natural variation). Our analysis shows that a revenue neutral tax policy could be a plausible policy alternative for achieving green objectives at minimal consumer welfare impacts, also contributing to slightly improve the quality of diet. In any case, it is also evident that, by comparing the impact of the two scenarios considered in this study, the impact increases as the level of the tax increases, suggesting that the tax level should be large enough to generate significant reduction in CO2-

\footnotetext{
${ }^{16}$ We have also carried out this analysis by social classes but we have not found any significant differences in relation to the average behaviour. Results are available from authors upon request.
} 
1 eq emissions. In other words, tax policies should be implemented as a complementary measure

2 to efficiently reduce such emissions.

3 A policy setback from our study could be border trade problems. The significant differential

4 between the prices of products sold in Catalonia, after the carbon tax imposition, and the same

5 products sold in neighbouring regions or countries could trigger a similar effect like the Danish

6 fat tax (see Vallgårda et al. 2015). If the tax is only applied to Catalonia ${ }^{17}$, consumers would

7 like to bypass the tax by shopping from neighbouring regions and, to a lesser extent, from

8 France if the transaction cost plus the non-taxed price is lower than the price paid for in

9 Catalonia. If the tax is applied in all Spain, the effectiveness for Catalonia would be higher as cross-border trade will take place only with south-east of France and the most populated towns are located more than one hundred kilometres from the border, making transaction costs high enough to compensate price differentials.

In any case, results from this study only apply to Catalonia and similar analyses that consider all food categories should be conducted for the country as a whole. Despite the contribution of this study to the policy discussion, we must recognize that our results should be interpreted with caution for several reasons: the most important is the lack of data. Although there are many studies on life-cycle analysis, most of them are product specific and no existing study covers a wide range of products in Catalonia using a common methodological approach. Second, we have assumed that the food supply is perfectly inelastic by ignoring potential strategic decisions of firms. Further research could be focused on relaxing this assumption. Finally, authors have assumed, due to data unavailability, a strong separability between foodat-home and food-away-from-home, other durable and non-durable goods. On the other hand, this limitation is difficult to overcome as we would need, at least, a composite indicator of

\footnotetext{
${ }^{17}$ Catalonia introduced only in its territory a sugar tax on soft drinks in 2018
} 
1 GHG emissions of other durable and non-durable goods. Despite these limitations, this study

2 provides some evidence about the potential impacts of imposing a $\mathrm{CO}_{2}$-eq tax on food products

3 and welfare in Catalonia.

\section{References}

5 Angulo, A.M., Nadhem, M., \& Gil, J. M. (2008). Analysis of the demand for food in Spain

6

7 considering the impact of diet on health." Economia Agraria y Recursos Naturales, 8(2), 3-30.

Baumol, W. J., \& Oates, W. E. (1975). The Theory of Environmental Policy: Externalities. Public Outlays, and the Quality of Life, 10-13.

Berardi, N., Sevestre, P., Tepaut, M., \& Vigneron, A. (2016). The impact of a 'soda tax'on prices: evidence from French micro data. Applied Economics, 48(41), 3976-3994.

Bonnet, C., Bouamra-Mechemache, Z., \& Corre, T. (2018). An Environmental Tax Towards More Sustainable Food: Empirical Evidence of the Consumption of Animal Products in France. Ecological $\quad$ Economics, $\quad$ 48-61. https://doi.org/10.1016/J.ECOLECON.2017.12.032

Bourne, M., Childs, J., Philippidis, G., \& Feijoo, M. (2012). Controlling greenhouse gas emissions in Spain: what are the costs for agricultural sectors? Spanish Journal of Agricultural Research, 10(3), 567-582.

Briggs, A. D. M., Mytton, O. T., Kehlbacher, A., Tiffin, R., Rayner, M., \& Scarborough, P. (2013). Overall and income specific effect on prevalence of overweight and obesity of 20\% sugar sweetened drink tax in UK: econometric and comparative risk assessment modelling study. BMJ (Clinical Research Ed.), 347, 1-17 https://doi.org/10.1136/BMJ.F6189 
1 Burchell, J., \& Lightfoot, S. (2001). Greening of the European Union: Examining the EU's Environmental Credentials (Vol. 14). London: Sheffield Academic Press.

3 Castellón, C. E., Boonsaeng, T., \& Carpio, C. E. (2015). Demand system estimation in the absence of price data: an application of Stone-Lewbel price indices. Applied Economics, 47(6), 553-568.

Colchero, M. A., Popkin, B. M., Rivera, J. A., \& Ng, S. W. (2016). Beverage purchases from stores in Mexico under the excise tax on sugar sweetened beverages: observational study. The Bmj, 352, 1-9. doi: https://doi.org/10.1136/bmj.h6704.

Cornelsen, L., \& Carreido, A. (2015). Health-related taxes on foods and beverages. beverages (Working Paper). Food Research Collaboration Policy Brief, 20. Retrieved from https://web.archive.org/web/20150828063003/http://foodresearch.org.uk/healthrelatedtaxes-on-food-and-beverages/.

Dhar, T., Chavas, J.-P., \& Gould, B. W. (2003). An empirical assessment of endogeneity issues in demand analysis for differentiated products. American Journal of Agricultural Economics, 85(3), 605-617.

Diewert, W. E. (1998). Index number issues in the consumer price index. The Journal of Economic Perspectives, 12(1), 47-58.

Edjabou, L. D., \& Smed, S. (2013). The effect of using consumption taxes on foods to promote climate friendly diets--The case of Denmark. Food Policy, 39, 84-96.

Endres, A. (2010). Environmental economics: theory and policy. Cambridge University Press.

Escobar, M. A. C., Veerman, J. L., Tollman, S. M., Bertram, M. Y., \& Hofman, K. J. (2013). Evidence that a tax on sugar sweetened beverages reduces the obesity rate: a meta- 
2 Garcia-Goñi, M., \& Hernández-Quevedo, C. (2012). The evolution of obesity in Spain. Eurohealth, 18(1), 22-25.

4 Garcia-Muros, X., Markandya, A., Romero-Jordán, D., \& González-Eguino, M. (2017). The 5 distributional effects of carbon-based food taxes. Journal of Cleaner Production, 140, 6 996-1006.

Hartikainen, H., \& Pulkkinen, H. (2016). Summary of the chosen methodologies and practices to produce GHGE-estimates for an average European diet. Natural resources and bioeconomy studies 58/2016. Natural Resources Institute, Finland.

Hedenus, F., Wirsenius, S., \& Johansson, D. J. A. (2014). The importance of reduced meat and dairy consumption for meeting stringent climate change targets. Climatic Change, 124(1-

Irz, X., Leroy, P., Réquillart, V., Soler, L.-G., \& others. (2015). ). Welfare and sustainability effects of dietary recommendations. TSE Working Papers 15-565, Toulouse School of

Jensen, J. D., \& Smed, S. (2013). The Danish tax on saturated fat--short run effects on consumption, substitution patterns and consumer prices of fats. Food Policy, 42, 18-31.

Laajimi, A., Gracia, A., \& Albisu, L. M. (1997). The demand for food in Spain: economic and demographic effects. Journal of International Food \& Agribusiness Marketing, 9(2), 1-

Lewbel, A., \& Pendakur, K. (2009). Tricks with Hicks: The EASI demand system. The American Economic Review, 99(3), 827-863. 
1 Máca, V., Melichar, J., \& Ščasn\y, M. (2012). Internalization of external costs of energy generation in central and eastern European countries. The Journal of Environment \& Development, 21(2), 181-197.

Molina, J. A. (1994). Food demand in Spain: An application of the almost ideal system. Journal of Agricultural Economics, 45(2), 252-258.

Mytton, O. T., Clarke, D., \& Rayner, M. (2012). Taxing unhealthy food and drinks to improve health. BMJ, 344(7857), 2931-2937.

Quinet, A. (2009). La valeur tutélaire du carbone, rapport du centre d’analyse stratégique, La Documentation Française. 16. http://www.ladocumentationfrancaise.fr/var/storage/ rapports-publics/094000195.pdf.

Ricciuto, L., Tarasuk, V., \& Yatchew, A. (2006). Socio-demographic influences on food purchasing among Canadian households. European Journal of Clinical Nutrition, 60(6), 778-790.

Säll, S., \& Gren, M. (2015). Effects of an environmental tax on meat and dairy consumption in Sweden. Food Policy, 55, 41-53.

Schmutzler, A., \& Goulder, L. H. (1997). The choice between emission taxes and output taxes under imperfect monitoring. Journal of Environmental Economics and Management, 32(1), 51-64.

Silver, M., \& Heravi, S. (2006). Why elementary price index number formulas differ: price dispersion and product heterogeneity. International Monetary Fund. $142-147$. 
1 Smed, S., Scarborough, P., Rayner, M., \& Jensen, J. D. (2016). The effects of the Danish saturated fat tax on food and nutrient intake and modelled health outcomes: an econometric and comparative risk assessment evaluation. European Journal of Clinical Nutrition, 70(6), 681-687.

Springmann, M., Mason-D’Croz, D., Robinson, S., Garnett, T., Godfray, H. C. J., Gollin, D., Scarborough, P. (2016). Global and regional health effects of future food production under climate change: a modelling study. The Lancet, 387(10031), 1937-1946.

Stern, N. H. (2007). The economics of climate change: the Stern review. cambridge University press.

Tol, R. S. J. (2012). A cost--benefit analysis of the EU 20/20/2020 package. Energy Policy, 49, 288-295.

Vallgårda S, Holm L, Jensen JD. The Danish tax on saturated fat: why did it not survive? Eur J Clin Nutr 2015; 69: 223-226

Wirsenius, S., Hedenus, F., \& Mohlin, K. (2011). Greenhouse gas taxes on animal food products: rationale, tax scheme and climate mitigation effects. Climatic Change, 108(12), 159-184.

Zhen, C., Brissette, I. F., \& Ruff, R. R. (2014). By ounce or by calorie: the differential effects of alternative sugar-sweetened beverage tax strategies. American Journal of Agricultural Economics, 96(4), 1070-1083. 


\section{Table 1 Household characteristic (\%)}

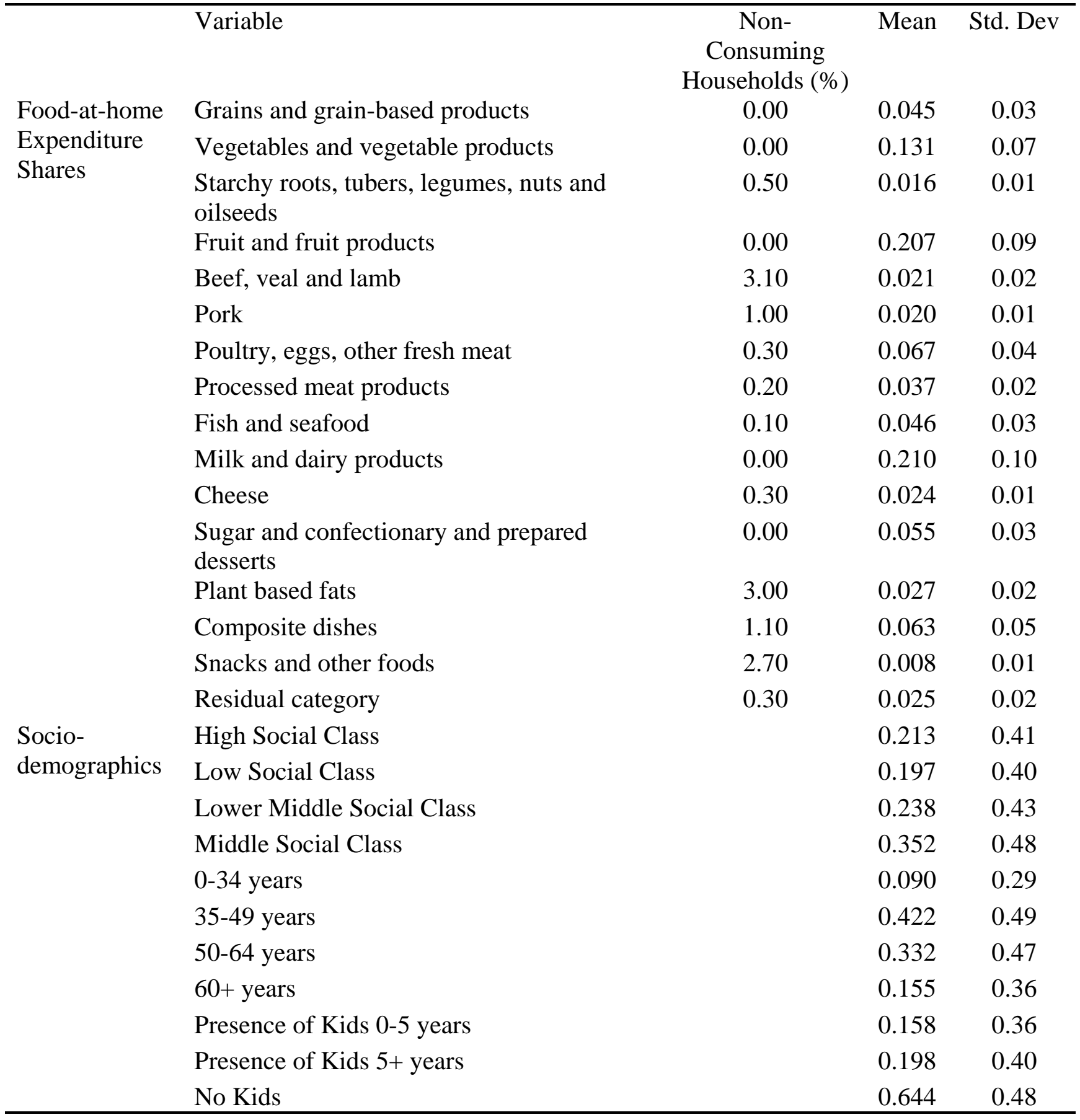


1 Table 2. Average kg CO2 equivalent emissions per kg for each food category

\begin{tabular}{lrr}
\hline Food Category & $\mathrm{kg}$ CO2-eq/kg food/day & Standard Deviation \\
\hline $\begin{array}{l}\text { Grains and grain-based } \\
\text { products }\end{array}$ & 1.10 & 0.30 \\
$\begin{array}{l}\text { Vegetables and vegetable } \\
\text { products }\end{array}$ & 1.20 & 0.70 \\
$\begin{array}{l}\text { Starchy roots, tubers, legumes, } \\
\text { nuts and oilseeds }\end{array}$ & 0.40 & 0.50 \\
Fruit and fruit products & 0.90 & 0.70 \\
Beef, veal and lamb & 18.90 & 11.70 \\
Pork & 5.80 & 0.20 \\
Poultry, eggs, other fresh meat & 5.90 & 1.70 \\
Processed meat products & 5.40 & 0.40 \\
Fish and seafood & 5.30 & 2.30 \\
Milk and dairy products & 1.50 & 0.10 \\
Cheese & 8.20 & 0.05 \\
Sugar and confectionary and & 1.20 & 0.50 \\
prepared desserts & 1.90 & 1.00 \\
Plant based fats & 2.60 & 8.60 \\
Composite dishes & 12.50 & 0.20 \\
Snacks and other foods & 1.30 & 0.30 \\
Residual category & &
\end{tabular}

2 Source: Own elaboration from Hartikainen \& Pulkkinen (2016) 
Table 3 Description of tax scenarios (taxed products and social cost emissions associated to each scenario)

\begin{tabular}{lcccc}
\hline & \multicolumn{2}{c}{$\begin{array}{c}\text { Uncompensated } \\
\text { Scenario }\end{array}$} & $\begin{array}{c}\text { Compensated } \\
\text { Scenario }\end{array}$ \\
\hline Scenario & U1 & U2 & C1 & C2 \\
\hline Food categories & & & & \\
Grains and grain-based products & $\mathrm{X}$ & $\mathrm{X}$ & & \\
Vegetables and vegetable products & $\mathrm{X}$ & $\mathrm{X}$ & & \\
Starchy roots, tubers, legumes, nuts and oilseeds & $\mathrm{X}$ & $\mathrm{X}$ & & \\
Fruit, fruit products and fruit and vegetable juices & $\mathrm{X}$ & $\mathrm{X}$ & & \\
Beef, veal and lamb & $\mathrm{X}$ & $\mathrm{X}$ & $\mathrm{X}$ & $\mathrm{X}$ \\
Pork & $\mathrm{X}$ & $\mathrm{X}$ & $\mathrm{X}$ & $\mathrm{X}$ \\
Poultry, eggs, other fresh meat & $\mathrm{X}$ & $\mathrm{X}$ & $\mathrm{X}$ & $\mathrm{X}$ \\
Processed and other cooked meats & $\mathrm{X}$ & $\mathrm{X}$ & $\mathrm{X}$ & $\mathrm{X}$ \\
Fish and other seafood & $\mathrm{X}$ & $\mathrm{X}$ & & \\
Milk, dairy products and milk product imitates & $\mathrm{X}$ & $\mathrm{X}$ & $\mathrm{X}$ & $\mathrm{X}$ \\
Cheese & $\mathrm{X}$ & $\mathrm{X}$ & $\mathrm{X}$ & $\mathrm{X}$ \\
Sugar and confectionary and prepared desserts & $\mathrm{X}$ & $\mathrm{X}$ & & \\
Plant based fats & $\mathrm{X}$ & $\mathrm{X}$ & & \\
Composite dishes & $\mathrm{X}$ & $\mathrm{X}$ & $\mathrm{X}$ & $\mathrm{X}$ \\
Snacks and other foods & $\mathrm{X}$ & $\mathrm{X}$ & & \\
Residual category & $\mathrm{X}$ & $\mathrm{X}$ & & \\
Social cost of emission & & & & \\
EU 2020 (56 Euro) & & & & \\
EU 2050 (200 Euro) & $\mathrm{X}$ & & $\mathrm{X}$ & \\
\hline
\end{tabular}

3

4

5

6

7

8

9

10 
Table 4 Price changes under alternative tax scenarios (\%)

\begin{tabular}{|c|c|c|c|c|}
\hline \multirow{2}{*}{$\begin{array}{l}\text { \% changes relative to baseline } \\
\text { Food Groups }\end{array}$} & \multicolumn{2}{|c|}{$\begin{array}{l}\text { UNCOMPENSATED } \\
\text { SCENARIOS }\end{array}$} & \multicolumn{2}{|c|}{$\begin{array}{c}\text { COMPENSATED } \\
\text { (REVENUE-NEUTRAL) } \\
\text { SCENARIOS }\end{array}$} \\
\hline & U1 & U2 & $\mathrm{C} 1$ & $\mathrm{C} 2$ \\
\hline $\begin{array}{l}\text { Grains and grain-based } \\
\text { products }\end{array}$ & $2 \%$ & $8 \%$ & $-6 \%$ & $-23 \%$ \\
\hline $\begin{array}{l}\text { Vegetables and vegetable } \\
\text { products }\end{array}$ & $4 \%$ & $13 \%$ & $-5 \%$ & $-19 \%$ \\
\hline $\begin{array}{l}\text { Starchy roots, tubers, legumes, } \\
\text { nuts and oilseeds }\end{array}$ & $0 \%$ & $2 \%$ & $-8 \%$ & $-27 \%$ \\
\hline $\begin{array}{l}\text { Fruit, fruit products and fruit } \\
\text { and vegetable juices }\end{array}$ & $4 \%$ & $13 \%$ & $-5 \%$ & $-19 \%$ \\
\hline Beef, veal and lamb & $12 \%$ & $44 \%$ & $12 \%$ & $44 \%$ \\
\hline Pork & $4 \%$ & $14 \%$ & $4 \%$ & $14 \%$ \\
\hline Poultry, eggs, other fresh meat & $9 \%$ & $33 \%$ & $9 \%$ & $33 \%$ \\
\hline $\begin{array}{l}\text { Processed and other cooked } \\
\text { meats }\end{array}$ & $4 \%$ & $13 \%$ & $4 \%$ & $13 \%$ \\
\hline Fish and other seafood & $3 \%$ & $12 \%$ & $-5 \%$ & $-19 \%$ \\
\hline $\begin{array}{l}\text { Milk, dairy products and milk } \\
\text { product imitates }\end{array}$ & $6 \%$ & $22 \%$ & $6 \%$ & $22 \%$ \\
\hline Cheese & $6 \%$ & $22 \%$ & $6 \%$ & $22 \%$ \\
\hline $\begin{array}{l}\text { Sugar and confectionary and } \\
\text { prepared desserts }\end{array}$ & $1 \%$ & $5 \%$ & $-7 \%$ & $-25 \%$ \\
\hline Plant based fats & $6 \%$ & $20 \%$ & $-3 \%$ & $-12 \%$ \\
\hline $\begin{array}{l}\text { Composite dishes (animal and } \\
\text { vegetable composite dishes) }\end{array}$ & $15 \%$ & $55 \%$ & $5 \%$ & $55 \%$ \\
\hline Snacks and other foods & $2 \%$ & $6 \%$ & $-7 \%$ & $-23 \%$ \\
\hline Residual category & $2 \%$ & $6 \%$ & $-7 \%$ & $-24 \%$ \\
\hline
\end{tabular}

* See Table 3 for the description of each scenario (subsidies are negative; taxes are positives). 
Table 5 Marshallian price elasticities at mean values

\begin{tabular}{|c|c|c|c|c|c|c|c|c|c|c|c|c|c|c|c|c|c|}
\hline Food category & Grains & Vegetables & $\begin{array}{l}\text { Pulse, } \\
\text { Legumes } \\
\text { and Starchy } \\
\text { roots }\end{array}$ & $\begin{array}{l}\text { Fruit and } \\
\text { vegetable } \\
\text { juices }\end{array}$ & $\begin{array}{l}\text { Beef, } \\
\text { veal and } \\
\text { lamb }\end{array}$ & Pork & $\begin{array}{l}\text { Poultry, } \\
\text { eggs, } \\
\text { other } \\
\text { fresh } \\
\text { meat } \\
\end{array}$ & 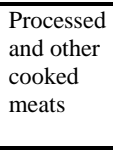 & $\begin{array}{l}\text { Fish and } \\
\text { other } \\
\text { seafood }\end{array}$ & $\begin{array}{l}\text { Milk, } \\
\text { dairy } \\
\text { and milk } \\
\text { product } \\
\text { imitates } \\
\end{array}$ & Cheese & $\begin{array}{l}\text { Sugar and } \\
\text { confectionary } \\
\text { and prepared } \\
\text { desserts }\end{array}$ & $\begin{array}{l}\text { Plant } \\
\text { based } \\
\text { fats }\end{array}$ & $\begin{array}{l}\text { Composite } \\
\text { dishes }\end{array}$ & $\begin{array}{l}\text { Snacks } \\
\text { and } \\
\text { other } \\
\text { foods }\end{array}$ & $\begin{array}{l}\text { Residual } \\
\text { category }\end{array}$ & $\begin{array}{l}\text { Food } \\
\text { Expenditure } \\
\text { Elasticity }\end{array}$ \\
\hline $\begin{array}{l}\text { Grains and grain- } \\
\text { based products }\end{array}$ & $-0.29 * *$ & $-0.18^{* *}$ & -0.04 & $-0.26^{* *}$ & -0.06 & -0.10 & $-0.10^{* *}$ & $\begin{array}{c}-0.03 \\
\end{array}$ & -0.04 & $-0.19^{* *}$ & -0.04 & 0.02 & -0.06 & -0.01 & 0.10 & 0.64 & $0.96 * *$ \\
\hline $\begin{array}{l}\text { Vegetables and } \\
\text { vegetable products }\end{array}$ & -0.10 & $-0.65^{* *}$ & 0.05 & -0.01 & -0.05 & -0.09 & $-0.17^{* *}$ & -0.10 & $0.32 * *$ & $-0.14^{* *}$ & 0.10 & -0.11 & -0.17 & $-0.11^{* *}$ & -0.10 & 0.31 & $1.21 * *$ \\
\hline $\begin{array}{l}\text { Starchy roots, tubers, } \\
\text { legumes, nuts and } \\
\text { oilseeds }\end{array}$ & $-0.05^{* *}$ & $-0.15^{* *}$ & $-0.61^{* *}$ & $-0.20^{* *}$ & $0.07 * *$ & 0.02 & $-0.06^{* *}$ & $-0.09 * *$ & $-0.04 *$ & $-0.19^{* *}$ & $0.05^{*}$ & $-0.07^{* *}$ & $-0.11^{* *}$ & $-0.10^{* *}$ & 0.06 & 0.07 & $0.78 * *$ \\
\hline $\begin{array}{l}\text { Fruit and fruit } \\
\text { ppoducts }\end{array}$ & $-0.21^{* *}$ & $0.19 * *$ & $0.34 * *$ & $-0.75^{* *}$ & -0.18 & $0.32^{* *}$ & $0.09 * *$ & $0.31^{* *}$ & -0.04 & -0.04 & -0.05 & 0.02 & $0.36 * *$ & -0.06 & 0.01 & -0.48 & $1.08 * *$ \\
\hline Beef. veal and lamb & $-0.06^{*}$ & $-0.16^{* *}$ & $0.10^{* *}$ & $-0.24 * *$ & $-0.16^{*}$ & $-0.22 * *$ & $-0.04 * *$ & $-0.10^{* *}$ & 0.01 & $-0.21^{* *}$ & 0.01 & 0.00 & -0.01 & $-0.04 * *$ & 0.11 & 0.11 & $0.92 * *$ \\
\hline Pork & $-0.08^{* *}$ & $-0.17^{* *}$ & 0.04 & $-0.19 * *$ & $-0.21 * *$ & $-0.80^{* *}$ & $-0.03^{* *}$ & $-0.18 * *$ & $-0.13^{* *}$ & $-0.21 * *$ & -0.07 & -0.02 & 0.00 & $-0.03 *$ & $0.22^{*}$ & $0.70^{* *}$ & $0.94 * *$ \\
\hline $\begin{array}{l}\text { Poultry, eggs, other } \\
\text { fresh meat }\end{array}$ & $-0.08^{* *}$ & $-0.21 * *$ & $0.07 * *$ & $-0.17 * *$ & $0.09 * *$ & $0.12^{* *}$ & $-0.85 * *$ & $0.08^{* *}$ & 0.01 & $-0.15^{* *}$ & $0.07^{* *}$ & $0.06^{* *}$ & $0.05^{* *}$ & $0.11^{* *}$ & $0.11^{* *}$ & 0.09 & $1.08 * *$ \\
\hline $\begin{array}{l}\text { Processed meats } \\
\text { products }\end{array}$ & -0.04 & $-0.18^{* *}$ & $-0.13^{* *}$ & $-0.16^{* *}$ & $-0.13^{*}$ & $-0.28 * *$ & -0.01 & $-0.34 * *$ & $0.15^{* *}$ & $-0.23 * *$ & 0.03 & $-0.07^{*}$ & $-0.12^{*}$ & $-0.04 * *$ & 0.08 & 0.13 & $0.91 * *$ \\
\hline Fish and seafood & -0.03 & -0.03 & 0.00 & $-0.22 * *$ & 0.10 & $-0.21 * *$ & $-0.04 * *$ & $0.21^{* *}$ & $-0.40 * *$ & $-0.20 * *$ & -0.11 & 0.00 & -0.04 & -0.06 & -0.13 & -0.50 & $0.99 * *$ \\
\hline $\begin{array}{l}\text { Milk and dairy } \\
\text { products }\end{array}$ & 0.03 & -0.05 & $0.20 * *$ & -0.05 & -0.05 & -0.06 & $0.10^{* *}$ & $-0.16^{* *}$ & -0.02 & $-0.64 * *$ & $0.17^{* *}$ & -0.01 & -0.10 & $0.12^{* *}$ & $0.29 * *$ & 0.39 & $0.99 * *$ \\
\hline Cheese & -0.05 & -0.14 & $0.09 * *$ & $-0.23 * *$ & 0.02 & -0.08 & $-0.04 * *$ & 0.00 & $-0.09 * *$ & $-0.19 * *$ & $-0.26^{* *}$ & 0.05 & $0.13 *$ & -0.01 & -0.06 & $-0.60 * *$ & $0.86 * *$ \\
\hline $\begin{array}{l}\text { Sugar and } \\
\text { confectionary and } \\
\text { prepared desserts }\end{array}$ & 0.03 & $-0.19 * *$ & -0.10 & $-0.21^{* *}$ & 0.11 & 0.06 & 0.01 & -0.07 & 0.01 & $-0.20 * *$ & $0.19^{* *}$ & $-0.58 * *$ & $-0.12 *$ & $0.05^{*}$ & -0.06 & 0.23 & $0.80 * *$ \\
\hline Plant based fats & $-0.07^{*}$ & $-0.19 * *$ & $-0.15^{* *}$ & $-0.17^{* *}$ & -0.01 & 0.01 & $-0.04 * *$ & $-0.10^{* *}$ & -0.06 & $-0.22 * *$ & $0.15^{* *}$ & $-0.09 * *$ & $-0.38 * *$ & $-0.09 * *$ & 0.05 & 0.35 & $0.84 * *$ \\
\hline Composite dishes & 0.02 & $-0.19 * *$ & $-0.21^{* *}$ & $-0.23 * *$ & 0.00 & 0.05 & $0.08^{* *}$ & -0.02 & $-0.06 *$ & $-0.16^{* *}$ & $0.09 * *$ & $0.07 *$ & $-0.11 * *$ & $-0.47 * *$ & 0.08 & 0.04 & $0.80 * *$ \\
\hline $\begin{array}{l}\text { Snacks and other } \\
\text { foods }\end{array}$ & -0.02 & $-0.16^{* *}$ & 0.02 & $-0.22 * *$ & 0.02 & $0.07 *$ & $-0.06 * *$ & -0.02 & $-0.07 * *$ & $-0.20 * *$ & -0.04 & $-0.05^{* *}$ & -0.01 & $-0.04 * *$ & $-0.67 * *$ & -0.07 & $0.61 * *$ \\
\hline Residual category & 0.32 & -0.09 & 0.13 & -0.28 & 0.14 & $0.89 * *$ & -0.03 & 0.07 & -0.30 & -0.16 & $-0.62^{* *}$ & 0.07 & 0.33 & -0.02 & -0.17 & -1.79 & $0.90 * *$ \\
\hline
\end{tabular}

**, * indicate significance at 5\% and 10\% respectively 
Figure 1 Mean reduction in $\mathrm{CO}_{2}$ equivalent emissions per person per day

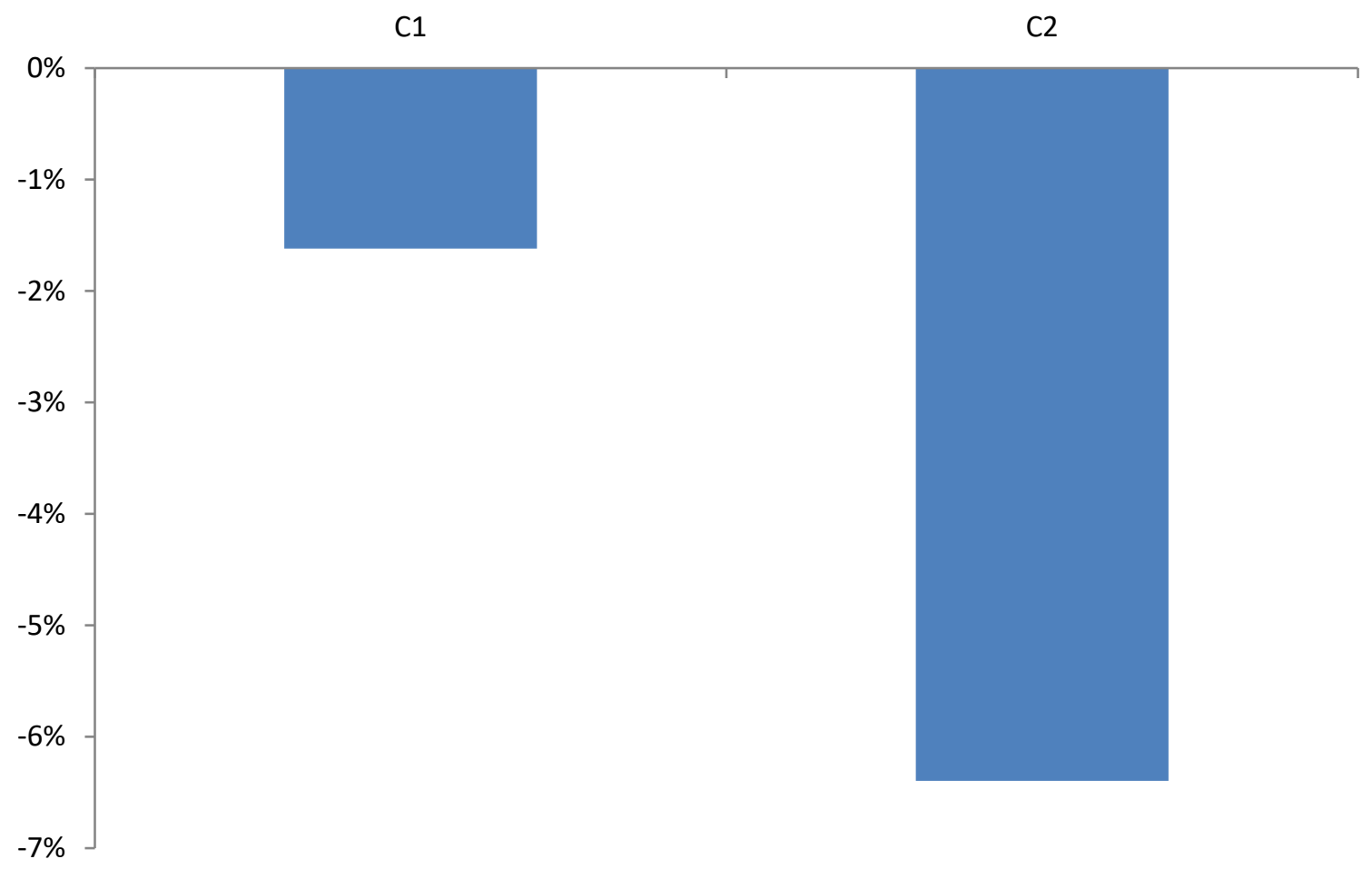

Note: See Table 3 for a description of the different tax scenarios 


\section{Figure 2 Reduction in consumption due to $\mathrm{CO}_{2}$ equivalent taxes}

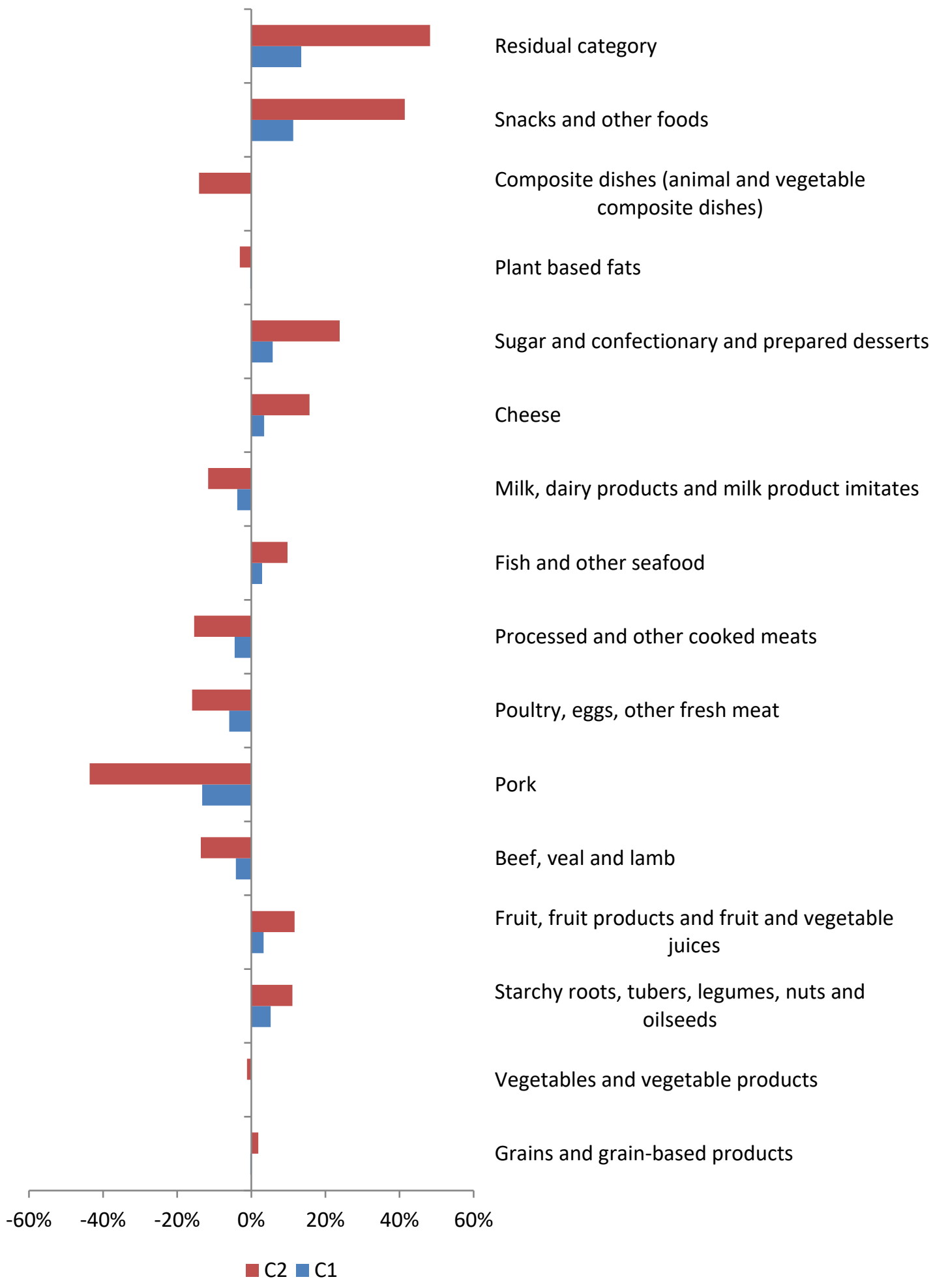

Note: See Table 3 for a description of the different tax scenarios 
Average Household

Head of the Household younger than 34 years

Head of the Household between 35-49 years

Head of the Household between 50-64 years

Head of the Household older than 60 years

Presence of kids younger than 5 years old

Presence of kids older than 5 years old

No kids
$-0.25$

0.41

$-0.10$

1.14

$-0.11$

0.98

$-0.24$

0.13

$-0.50$

$-1.03$

$-0.10$

0.58

$-0.02$

1.16

$-0.28$

0.21

Note: See Table 3 for a description of the different tax scenarios 
Figure 3 Impact of CO2-eq tax on diet quality

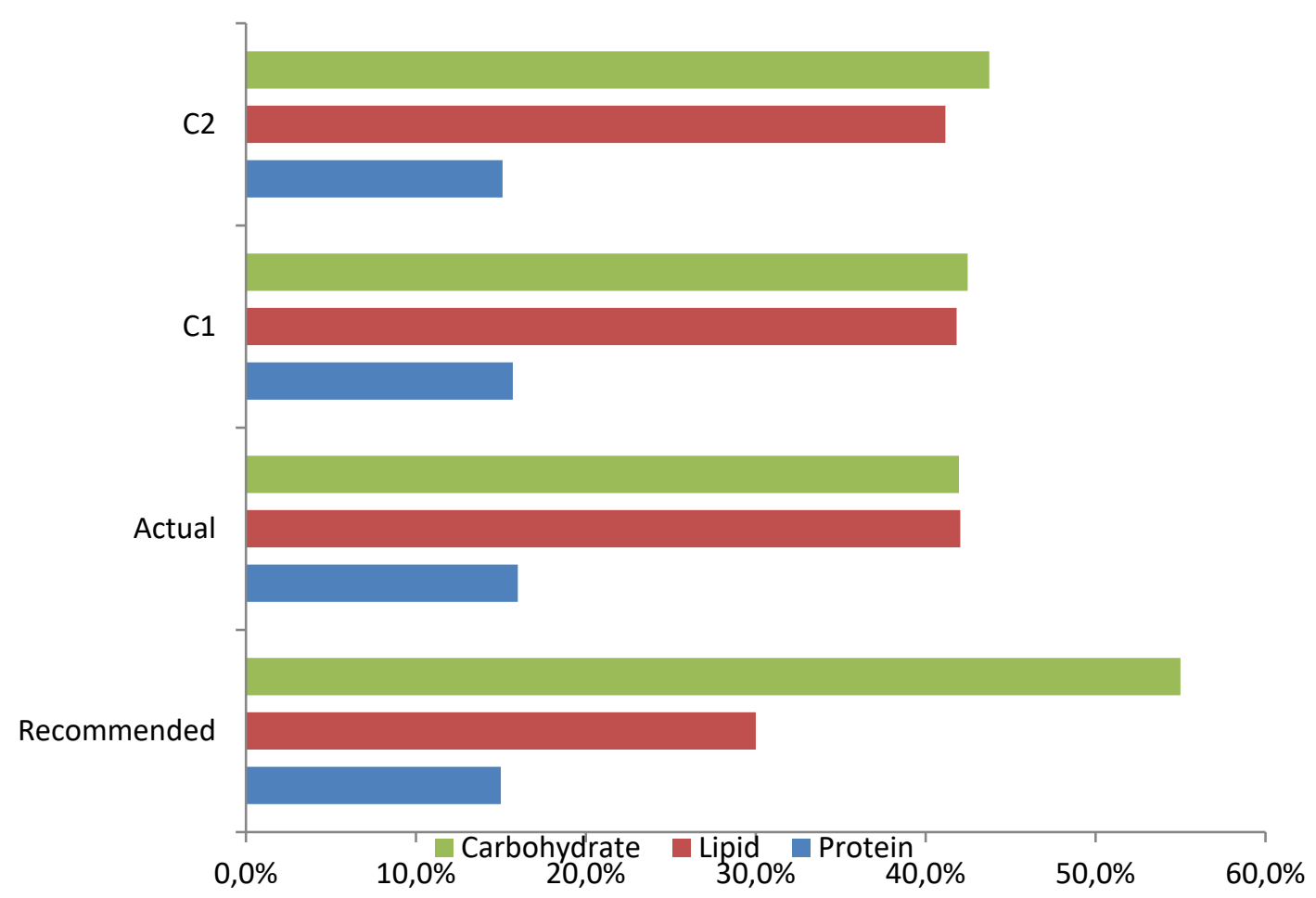

Note: See Table 3 for a description of the different tax scenarios 
Figure 4 Impact of CO2-eq tax on nutrient compositions

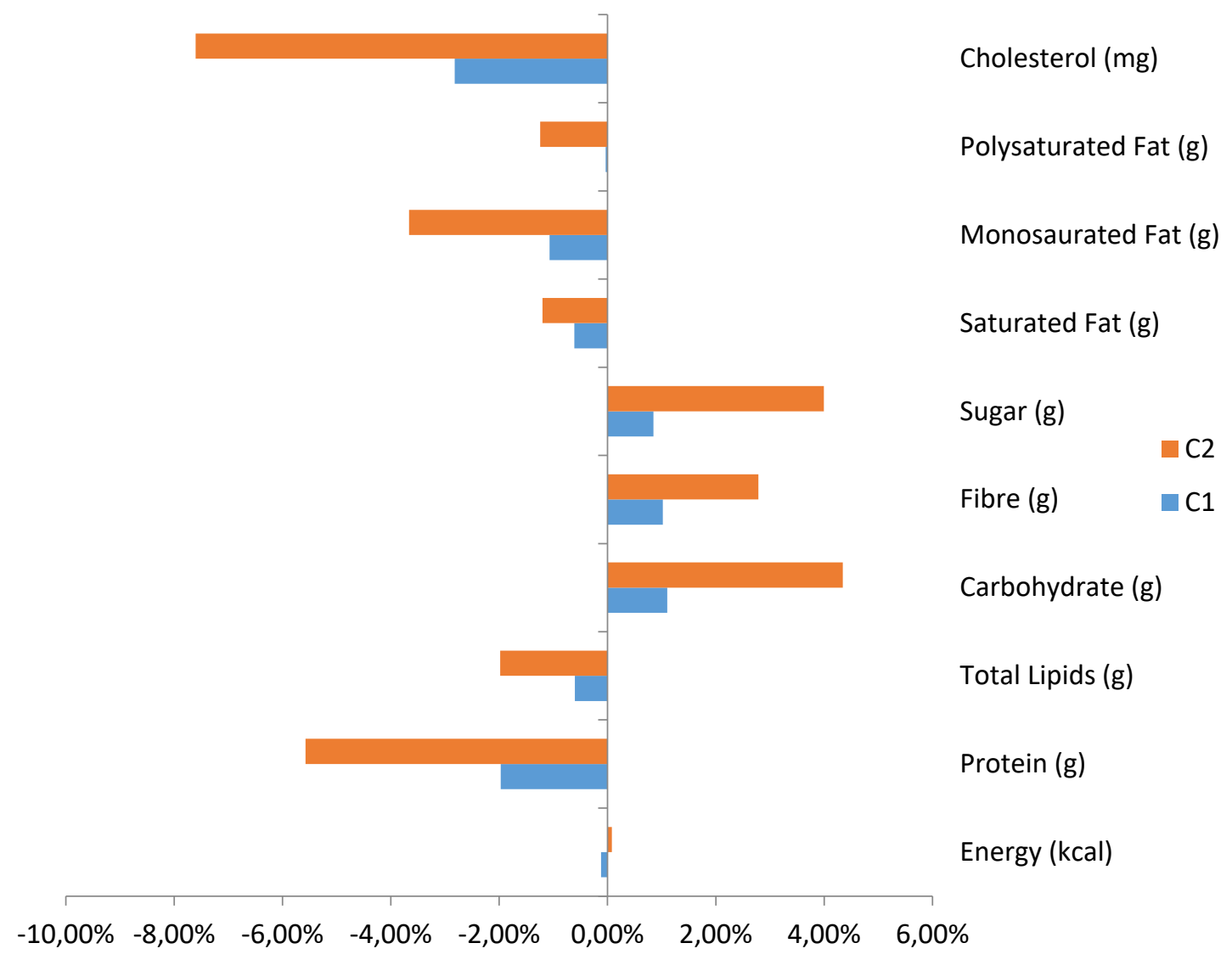

Note: See Table 3 for a description of the different tax scenarios 


\section{Appendix}

Own- and expenditure elasticity estimates from the QUAIDS model

\begin{tabular}{lll}
\hline Food Category & $\begin{array}{l}\text { Expenditure } \\
\text { Elasticities }\end{array}$ & Price Elasticities \\
\hline & QUAIDS & QUAIDS \\
Grains and grain-based products & 1.00 & -0.24 \\
Vegetables and vegetable products & 1.12 & -0.68 \\
Starchy roots, tubers, legumes, nuts and & 0.85 & -0.60 \\
oilseeds & & \\
Fruit, fruit products and fruit and vegetable & 1.03 & -0.77 \\
juices & & -0.22 \\
Beef, veal and lamb & 0.77 & -0.70 \\
Pork & 1.00 & -0.85 \\
Poultry, eggs, other fresh meat & 1.12 & -0.36 \\
Processed and other cooked meats & 1.04 & -0.45 \\
Fish and other seafood & 1.00 & -0.70 \\
Milk, dairy products and milk product & 0.97 & -0.53 \\
imitates & & -0.57 \\
Cheese & 0.90 & -0.41 \\
Sugar and confectionary and prepared & 0.89 & -0.56 \\
desserts & & -0.69 \\
Plant based fats & 0.78 & \\
Composite dishes (animal and vegetable & 0.98 & \\
composite dishes) & & \\
Snacks and other foods & 0.88 & \\
Residual Category & 0.94 & \\
\hline
\end{tabular}

